\title{
DEVOLVAM NOSSO DINHEIRO: GUERRA CONTRA A CORRUPÇÃO VENCE MAIS UMA BATALHA
}

Coluna publicada em 21.8.2018: <https://www.conjur.com.br/2018-ago-21/ contas-vista-guerra-corrucao-vence-batalha $>$

A luta contra a corrupção é uma guerra permanente e, como todas, composta de muitas batalhas que precisam ser vencidas. É previsível que não são nem serão fáceis. Nas últimas semanas, tivemos um exemplo delas, em razão de importante ação julgada pelo Supremo Tribunal Federal ${ }^{1}$ que teve ampla cobertura da mídia. ${ }^{2}$

No julgamento do RE 852.475, discutia-se a possibilidade de prescrição das açōes de ressarcimento por danos ao erário. Iniciado o julgamento, tendo o relator e cinco ministros votado a favor da tese do reconhecimento da prescrição após decorridos cinco anos, o ministro Luiz Edson Fachin abriu divergência, convenceu os demais ministros e houve até mudança de posição dos ministros Luiz Fux e Roberto Barroso, que já haviam votado, e ao final o julgamento acolheu sua tese, pela apertada margem de 6 votos a 5, no sentido de não admitir a prescrição nesses casos.

1 RE 852.475/SP, julgamento ocorrido nos dias 2 e 8 de agosto.

2 Maioria no STF é a favor de prescrição de dever de ressarcir erário em cinco anos (ConJur, 2 de agosto de 2018); "Dodge diz que decisão do STF sobre improbidade pode dificultar combate à corrupção" (UOL, 6 de agosto de 2018); "Dodge critica prazo de 5 anos para prescrição de ações” (Valor Econômico, 7 de agosto de 2018); Dever de ressarcir o erário por improbidade não prescreve, decide Supremo (ConJur, 8 de agosto de 2018); "Em reviravolta, STF diz que não há prazo para cobrar ressarcimento em improbidade" (Jota, 8 de agosto de 2018); "Supremo decide que ações para ressarcir cofres públicos não prescrevem" (Folha de S.Paulo, 8 de agosto de 2018); "STF decide que não há prazo para cobrança na Justiça de dinheiro público desviado de forma dolosa" (G1, 8 de agosto de 2018); "Julgamento no Supremo ameaça retorno de dinheiro da Lava Jato" (O Estado de S.Paulo, 8 de agosto de 2018); "STF decide que não há prazo para devolução de dinheiro público desviado" (Exame, 8 de agosto de 2018); “"Errônea ideia de imprescritibilidade causará insegurança jurídica', diz Moraes" (ConJur, 9 de agosto de 2018). 
Como bem observou o ministro Fachin, "não há incompatibilidade com o Estado Democrático de Direito, ou com o Estado de Direito Democrático, sustentar a imprescritibilidade das ações de ressarcimento em matéria de probidade, eis que não rara a prescrição é o biombo por meio do qual se encobre a corrupção e o dano ao interesse público".

Ou seja, por muito pouco não se abriu margem à impunidade para aqueles que causam prejuízos aos cofres públicos, como ocorre com a maior parte dos casos que envolvem atos de corrupção.

Para que se tenha uma visão rápida e superficial do caso em discussão, trata-se de ação de improbidade administrativa movida pelo Ministério Público de São Paulo em que houve condenação de gestor público por ato de improbidade administrativa que resultou em dano ao patrimônio público, pelo qual foi condenado ao ressarcimento, além das demais penalidades cabíveis.

Discutiu-se a interpretação do disposto no artigo 37 , $\$ \$ 4^{\circ}$ e $5^{\circ}$ da Constituição, no que tange à previsão do dever de ressarcimento ao erário nos atos de improbidade administrativa e eventual prescrição aplicável. ${ }^{3}$

O relator, ministro Alexandre de Moraes, defendeu a tese da aplicação do artigo 23 da Lei de Improbidade Administrativa (Lei 8.429/1992), que prevê a prescrição da pretensão punitiva em cinco anos, devendo ser aplicada essa regra, pois a imprescritibilidade fere os princípios da segurança jurídica e ampla defesa, e não se enquadram na hipótese de exceçôes à imprescritibilidade contidas no artigo 37, XLII e XLIV da Constituição.

Prevaleceu, no entanto, por apertada maioria, o argumento do ministro Fachin, segundo o qual a ressalva contida no $\$ 5^{\circ}$ do artigo 37 tem a função justamente de reconhecer a imprescritibilidade das ações cíveis de ressarcimento ao erário fundadas na prática de ato de improbidade administrativa. A tese do Tema 897 da sistemática da repercussão geral ficou assim redigida: "São imprescritíveis as ações de ressarcimento ao erário fundadas na prática de ato doloso tipificado na Lei de Improbidade Administrativa".

Se não acolhida a tese do ministro Fachin, ficaria enfraquecida a luta contra a corrupção e em muito prejudicaria o esforço que vem sendo feito na recuperação de dinheiro desviado por corrupção, como se tem visto ultimamente, ainda que

3 O artigo 37, $\$ 5^{\circ}$, prevê: “A lei estabelecerá os prazos de prescrição para ilícitos praticados por qualquer agente, servidor ou não, que causem prejuízos ao erário, ressalvadas as respectivas ações de ressarcimento". 
por outros instrumentos jurídicos, como os recentes casos decorrentes da operação "lava jato". ${ }^{4}$

Diante do resultado, mantém-se agora firmes os poderes de pessoas e órgãos que estão na linha de frente desse combate, como é o caso do Ministério Público.

Limitar a possibilidade de promover ações de ressarcimento em atos de improbidade administrativa ao prazo prescricional de cinco anos é um benefício que acabaria por beneficiar os "malfeitores" do erário, o que é inaceitável nos tempos atuais. No mais das vezes, esses atos envolvem irregularidades complexas, difíceis de serem apuradas e comprovadas, sendo o prazo de cinco anos invariavelmente insuficiente para permitir que se aplique ampla e devida punição e que, mais importante do que isso, se facilite a recuperação dos recursos públicos.

O caso em questão trata especificamente da aplicação da prescrição da pretensão de ressarcimento ao erário em caso de improbidade administrativa, em razão de ação movida pelo Ministério Público no exercício de sua competência, evidenciando a importância desse órgão não só no combate à corrupção, como também e principalmente na recuperação dos recursos desviados do erário, como se tem visto com frequência.

Mas esse fato traz uma boa oportunidade para destacar as importantes funções dos tribunais de contas na defesa do erário e na recuperação de recursos desviados dos cofres públicos. Principais órgãos responsáveis pela fiscalização das contas públicas, os tribunais de contas, verdadeiros "guardiōes do dinheiro público", dispõem de importante função sancionatória e poder punitivo em face dos agentes públicos que causam prejuízos aos cofres públicos, além de capacidade de recuperar recursos desviados.

E mostrar também que o ordenamento jurídico em matéria de Direito Financeiro tem instrumentos que precisam ser conhecidos e utilizados em defesa do erário na luta contra esses "malfeitores" das finanças públicas.

Causar prejuízo aos cofres públicos, como se pode constatar, promove danos extremamente graves, pois os recursos desviados afetam diretamente a ação do Estado, prejudicando a execução das políticas governamentais e o atendimento das necessidades públicas, e não há mais como ser aceito. A sociedade brasileira está verdadeiramente com "tolerância zero" para esses atos. Clama por um endurecimento no tratamento desse tema e rigor cada vez maior na punição dos responsáveis.

"Lava-jato faz quatro anos e recupera R \$ 11,5 bi por meio de acordos" (UOL, 11 de março de 2018). Veja a coluna Tribunais de contas são os guardióes do dinheiro público, nesta edição, p. 317-322. 
A legislação e doutrina brasileiras não definem claramente essas questões, e a responsabilização pelos danos ao erário vinha sendo tratada de forma difusa em vários diplomas normativos e em vários ramos do Direito.

Emerson Gomes, em sua obra Responsabilidade financeira, sistematiza a questão, identificando a responsabilidade financeira como sendo uma categoria jurídica autônoma, que se diferencia das espécies tradicionais de responsabilidade (civil, penal, administrativa e por improbidade administrativa), não obstante haver pontos de intersecção. ${ }^{6} \mathrm{~A}$ responsabilidade financeira pode ser definida, segundo o autor, como sendo "a obrigação de repor recursos públicos (imputação de débito) ou de suportar as sanções previstas em lei, no âmbito do controle financeiro exercidos pelos Tribunais de Contas, em razão da violação de normas pertinentes à gestão de bens, dinheiros e valores públicos ou dos recursos privados sujeitos à guarda e administração estatal".

No Direito português, que reconhece expressamente a categoria da responsabilidade financeira, vê-se que podem ser identificadas duas modalidades, a sancionatória e a reintegratória. ${ }^{8}$ A responsabilidade sancionatória "compreende a aplicação de sanção pecuniária, multa, no caso de infrações essencialmente financeiras e infrações não essencialmente financeiras". ' Os tribunal de contas no Brasil podem aplicar multas, conforme expressamente prevê o artigo 71, VIII, que têm eficácia de título executivo (art. $71, \S 3^{\circ}$ ). A responsabilidade reintegratória "importa na obrigação de repor as quantias correspondentes ao dano patrimonial causado ao Erário em razão da violação de normas e princípios pertinentes à gestão de bens, dinheiros e valores públicos". ${ }^{10}$

O caso discutido no STF relata precisamente uma hipótese de ato de improbidade administrativa que importou em dano ao erário, caso típico de responsabilidade reintegratória, devendo o infrator ressarcir os prejuízos causados aos cofres públicos.

No âmbito dos tribunais de contas, a conduta dolosa ou culposa do gestor de recursos públicos que implique dano ao erário acarretava a responsabilidade finan-

6 GOMES, Emerson C. S. Responsabilidade financeira - uma teoria sobre a responsabilidade no âmbito dos tribunais de contas. Porto Alegre: Núria Fabris, 2012. p. 337.

7 GOMES, Emerson C. S. Responsabilidade financeira - uma teoria sobre a responsabilidade no âmbito dos tribunais de contas. Op. cit., p. 35-36.

8 TAVARES, José F. F. O Tribunal de Contas. Coimbra: Almedina, 1998. p. 241.

9 GOMES, Emerson C. S. Responsabilidade financeira - uma teoria sobre a responsabilidade no âmbito dos tribunais de contas. Op. cit., p. 134.

10 GOMES, Emerson C. S. Responsabilidade financeira - uma teoria sobre a responsabilidade no âmbito dos tribunais de contas. Op. cit., p. 160. 
ceira reintegratória. A Lei 13.655/2018 alterou um pouco essa sistemática, e o gestor público passou a responder somente em caso de dolo ou erro grosseiro. ${ }^{11}$

Por sua vez, a questão da "prescritibilidade da pretensão de ressarcimento ao erário fundada em decisão de Tribunal de Contas" ainda será apreciada pelo STF no RE 636.886, sob relatoria do ministro Alexandre de Moraes (Tema 899 da repercussão geral). É possível que o Supremo considere prescritíveis tais pretensões tendo em vista, principalmente, que as condenações dos tribunais de contas são oriundas de condutas culposas, o que tem a ver com os meios de prova disponíveis às cortes de contas.

De qualquer forma, é certo que os tempos mudaram, como se pode ver. $\mathrm{O}$ Brasil tornou-se intolerante com a corrupção em suas diversas modalidades, que se transformou em preocupação "número 1" de toda a sociedade. O "Brasil que eu quero" não admite mais a corrupção, como se pode facilmente constatar. $\mathrm{O}$ tempo em que os ricos e poderosos não iam para a cadeia já ficou para trás, uma fase superada e exemplo para o mundo. Os complexos penitenciários de Pinhais, na região de Curitiba, e da Papuda, em Brasília, estão aí para demonstrar, com seus "hóspedes" que um dia já foram ilustres personalidades.

O dinheiro público é de todos. Não se pode afrouxar essas regras. Não podemos todos pagar a conta daqueles que dele se apropriaram, usaram e agora querem ficar livres da obrigação de devolver o dinheiro que é e sempre foi nosso.

11 Art. 28. O agente público responderá pessoalmente por suas decisões ou opiniōes técnicas em caso de dolo ou erro grosseiro. 
